\title{
Enhanced Small-Molecule Assembly through Directional Intramolecular Forces
}

A. J. Lampkins, O. Abdul-Rahim, H. Li, and Ronald K. Castellano*

Department of Chemistry, University of Florida, Gainesville, FL 32611

\section{SYNTHESIS}

General. Reagents and solvents were purchased from Acros, Aldrich, or Fluka and used without further purification unless otherwise specified (including $\mathrm{N}$-phenylacetamide 6). THF, ether, $\mathrm{CH}_{2} \mathrm{Cl}_{2}$, and DMF were degassed in $20 \mathrm{~L}$ drums and passed through two sequential purification columns (activated alumina; molecular sieves for DMF) under a positive argon atmosphere using the GlassContour solvent system (GlassContour, Inc.). Thin layer chromatography (TLC) was performed on DURASIL TLC aluminum sheets with visualization by UV light or staining. Melting points (m.p.) were determined on a MEL-TEMP melting apparatus and are uncorrected. ${ }^{1} \mathrm{H}(300)$ and ${ }^{13} \mathrm{C}$ NMR $(75$ $\mathrm{MHz}$ ) spectra were recorded on a Varian Mercury 300 spectrometer. Chemical shifts $(\delta)$ are given in parts per million $(\mathrm{ppm})$ relative to TMS and referenced to residual protonated solvent $\left(\mathrm{CHCl}_{3}: \delta_{\mathrm{H}} 7.27\right.$ ppm, $\delta_{\mathrm{C}} 77.00 \mathrm{ppm}$ ). Abbreviations used are s (singlet), d (doublet), t (triplet), q (quartet), quin (quintet), b (broad), and $\mathrm{m}$ (multiplet). MS spectra (HRMS and LRMS) were recorded on a Finnigan MAT95Q Hybrid Sector spectrometer. UV-Vis spectra were recorded using a Shimadzu UV-1700 UV-Visible spectrophotometer. 1,3,5-Tris(bromomethyl)-2,4,6-trimethoxybenzene 3 was prepared as previously reported. ${ }^{[1]}$ The synthesis of $\mathbf{1 b}$ will be reported elsewhere.<smiles>COc1c(CC#N)c(OC)c(CC#N)c(OC)c1CC#N</smiles>

(1,3,5-Tris-cyanomethyl-2,4,6-trimethoxy-phenyl)-acetonitrile (3-CN). To a refluxing solution of 1,3,5-tris-bromomethyl-2,4,6-trimethoxybenzene 3 (1.00 g, $2.24 \mathrm{mmol})$ in acetone (75 $\mathrm{mL})$ was added $\mathrm{KCN}$ (0.641 g, $9.84 \mathrm{mmol})$. To the resulting suspension, water $(70 \mathrm{~mL})$ was slowly added over 15 minutes and the solution was allowed to reflux overnight. After cooling to room temperature, the reaction mixture was poured into ice water $(150 \mathrm{~mL})$ and suction filtered as soon as the ice melted. The filtered solid was thoroughly dried under reduced pressure to afford 3-CN $(0.430 \mathrm{~g}, 67 \%)$ as a colorless solid: ${ }^{1} \mathrm{H}$ NMR (DMSO- $\left.d_{6}\right) \delta 3.84(\mathrm{~s}, 9 \mathrm{H}), 3.90(\mathrm{~s}, 6 \mathrm{H}) .{ }^{13} \mathrm{C}$ NMR (DMSO- $\left.d_{6}\right) \delta 13.0,62.5,116.4$, 119.0, 158.0. HRMS (ESI) calcd for $\mathrm{C}_{15} \mathrm{H}_{15} \mathrm{~N}_{3} \mathrm{O}_{3}(\mathrm{M}+\mathrm{Na})^{+} 308.1006$, found 308.1011 .<smiles>COc1c(CC(=O)O)c(OC)c(CC(=O)O)c(OC)c1CC(=O)O</smiles>

4

(1,3,5-Tris-carboxymethyl-2,4,6-trimethoxy-phenyl)-acetic acid (4). A solution of trinitrile 3-CN $(0.300 \mathrm{~g}, 1.05 \mathrm{mmol}), \mathrm{NaOH}(4.21 \mathrm{~g}, 105 \mathrm{mmol})$, ethanol $(7 \mathrm{~mL})$, and water $(8 \mathrm{~mL})$ was heated at 100 ${ }^{\circ} \mathrm{C}$ in a sealed pressure tube for 10 hours. The resulting orange solution was acidified to $\mathrm{pH}=2 \mathrm{with}$ 
conc. $\mathrm{HCl}$, cooled to ca. $10{ }^{\circ} \mathrm{C}$, and suction filtered. The filtrate was diluted with brine and extracted with ethyl acetate $(50 \mathrm{~mL} \times 3)$. The organic extracts were combined, dried over $\mathrm{MgSO}_{4}$, and evaporated in vacuo to afford $4(0.356 \mathrm{~g}, 99 \%)$, as an off-white solid: ${ }^{1} \mathrm{H}$ NMR (DMSO- $\left.d_{6}\right) \delta 3.52(\mathrm{~s}$, $6 \mathrm{H}), 3.64(\mathrm{~s}, 9 \mathrm{H}), 12.34(\mathrm{~s}, 3 \mathrm{H}) .{ }^{13} \mathrm{C} \mathrm{NMR}\left(\mathrm{DMSO}-d_{6}\right) \delta 30.1,60.8,118.6,157.0,173.0$. HRMS (ESI) calcd for $\mathrm{C}_{15} \mathrm{H}_{18} \mathrm{O}_{9}(\mathrm{M}+\mathrm{Na})^{+}$365.0843, found 365.0825 .<smiles>COc1c(CC(=O)Nc2ccccc2)c(OC)c(CC(=O)Nc2ccccc2)c(OC)c1CC(=O)Nc1ccccc1</smiles>

$\mathrm{N}$-Phenyl-2-(2,4,6-trimethoxy-3,5-bis-phenylcarbamoylmethyl-phenyl)-acetamide (5a). A solution of triacid $4(0.32 \mathrm{~g}, 0.93 \mathrm{mmol})$ and thionyl chloride was refluxed for 2 hours and the solvent removed in vacuo. The remaining crude brown oil (4-Cl) was then dissolved in dry THF (10 mL) and slowly added to a solution of aniline $(0.51 \mathrm{~mL} 5.6 \mathrm{mmol})$, TEA $(1.3 \mathrm{~mL}, 9.3 \mathrm{mmol})$, and dry THF $(10 \mathrm{~mL})$ in a dry round bottom flask. The resulting solution was allowed to stir under a blanket of argon overnight. The reaction mixture was then diluted with methylene chloride $(50 \mathrm{~mL})$, washed with $10 \%$ aq. $\mathrm{HCl}(25$ $\mathrm{mL})$, water $(20 \mathrm{~mL})$, brine $(20 \mathrm{~mL})$, dried over $\mathrm{MgSO}_{4}$, and evaporated in vacuo to afford $5 \mathbf{a}(0.47 \mathrm{~g}$, $89 \%$ ) as a peach-colored solid: ${ }^{1} \mathrm{H} \mathrm{NMR}\left(\mathrm{CDCl}_{3}\right) \delta 3.81(\mathrm{~s}, 6 \mathrm{H}), 3.94(\mathrm{~s}, 9 \mathrm{H}), 7.07(\mathrm{t}, J=7.5 \mathrm{~Hz}, 3 \mathrm{H})$, $7.24(\mathrm{t}, J=7.5 \mathrm{~Hz}, 6 \mathrm{H}), 7.43(\mathrm{~d}, J=7.5 \mathrm{~Hz}, 6 \mathrm{H}), 8.04(\mathrm{~s}, 3 \mathrm{H}) . \quad\left(\mathrm{DMSO}-d_{6}\right) \delta 3.69(\mathrm{~s}, 6 \mathrm{H}), 3.71(\mathrm{~s}$, 9H), 7.03 (t, $J=7.2 \mathrm{~Hz}, 3 \mathrm{H}), 7.29$ (t, $J=7.8 \mathrm{~Hz}, 6 \mathrm{H}), 7.61(\mathrm{~d}, J=7.8 \mathrm{~Hz}, 6 \mathrm{H}), 10.22(\mathrm{~s}, 3 \mathrm{H}) .{ }^{13} \mathrm{C}$ NMR (DMSO-d $)) \delta 32.8,61.7,119.5,119.8,123.5,129.2,139.9,157.9,170.1$. HRMS (ESI) calcd for $\mathrm{C}_{33} \mathrm{H}_{33} \mathrm{~N}_{3} \mathrm{O}_{6}+\mathrm{Na}\left(\mathrm{M}^{+}\right)$590.2262, found 590.2270.

${ }^{15} \mathrm{~N}$-Phenyl-2-(2,4,6-trimethoxy-3,5-bis-phenylcarbamoylmethyl-phenyl)-acetamide (5a*). This compound was synthesized from triacid chloride 4-Cl $(0.61 \mathrm{~g}, 1.77 \mathrm{mmol}),{ }^{15} \mathrm{~N}$-aniline $(0.52 \mathrm{~g}, 5.49$ mmol), and TEA $(2.5 \mathrm{~mL}, 18 \mathrm{mmol})$ according to the same procedure reported for 5a to afford 5a* $(0.91 \mathrm{~g}, 90 \%)$ as an orange solid: ${ }^{1} \mathrm{H}$ NMR $\left(\mathrm{DMSO}-d_{6}\right) \delta 3.70(\mathrm{~s}, 6 \mathrm{H}), 3.72(\mathrm{~s}, 9 \mathrm{H}), 7.03(\mathrm{t}, J=7.5 \mathrm{~Hz}$, $3 \mathrm{H}), 7.30(\mathrm{t}, J=7.2 \mathrm{~Hz}, 6 \mathrm{H}), 7.61(\mathrm{~d}, J=7.5 \mathrm{~Hz}, 6 \mathrm{H}), 10.20(\mathrm{~d}, J=90.3 \mathrm{~Hz}, 3 \mathrm{H}) .{ }^{13} \mathrm{C}$ NMR (DMSO$\left.d_{6}\right) \delta 32.2,61.2,119.0,119.2,122.9,128.6,139.4,157.4,169.6$. HRMS (EI) calcd for $\mathrm{C}_{33} \mathrm{H}_{33}{ }^{15} \mathrm{~N}_{3} \mathrm{O}_{6}$ $\left(\mathrm{M}^{+}\right)$570.2369, found 570.2278.

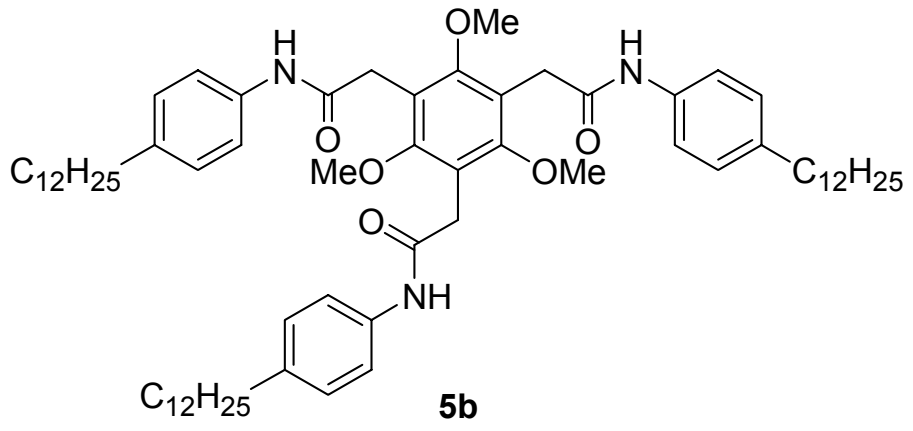

2-\{3,5-Bis-[(4-dodecyl-phenylcarbamoyl)-methyl]-2,4,6-trimethoxy-phenyl $\}-N$-(4-dodecylphenyl)-acetamide (5b). This compound was synthesized from triacid chloride 4-Cl (1.15 g, 2.90 
mmol), 4-dodecylaniline $(2.50 \mathrm{~g}, 9.56 \mathrm{mmol})$, and TEA $(4.1 \mathrm{~mL}, 29 \mathrm{mmol})$ according to the same procedure reported for $\mathbf{5 a}$ to afford $\mathbf{5 b}(2.20 \mathrm{~g}, 71 \%)$ as an off-white solid: ${ }^{1} \mathrm{H}$ NMR $\left(\mathrm{CDCl}_{3}\right) \delta 0.88(\mathrm{t}$, $J=7.2 \mathrm{~Hz}, 9 \mathrm{H}), 1.25(\mathrm{~m}, 54 \mathrm{H}), 1.54(\mathrm{~m}, 6 \mathrm{H}), 2.51(\mathrm{t}, J=7.5 \mathrm{~Hz}, 6 \mathrm{H}), 3.69(\mathrm{~s}, 6 \mathrm{H}), 3.80(\mathrm{~s}, 9 \mathrm{H}), 6.98$ $(\mathrm{d}, J=8.1 \mathrm{~Hz}, 6 \mathrm{H}), 7.31(\mathrm{~d}, J=8.1 \mathrm{~Hz}, 6 \mathrm{H}), 8.29(\mathrm{~s}, 3 \mathrm{H}) .{ }^{13} \mathrm{C} \mathrm{NMR}\left(\mathrm{CDCl}_{3}\right) \delta 14.1,22.7,29.3,29.6$, 29.7, 31.6, 31.9, 33.7, 35.4, 62.1, 120.1, 128.6, 135.5, 138.8, 157.4, 169.0. HRMS (ESI) calcd for $\mathrm{C}_{69} \mathrm{H}_{105} \mathrm{~N}_{3} \mathrm{O}_{6}+\mathrm{Na}\left(\mathrm{M}^{+}\right)$1094.7896, found 1094.7895 .<smiles>O=C(Cc1c(O)c(CC(=O)Nc2ccccc2)c(O)c(CC(=O)Nc2ccccc2)c1O)Nc1ccccc1</smiles>

N-Phenyl-2-(2,4,6-trihydroxy-3,5-bis-phenylcarbamoylmethyl-phenyl)-acetamide (7a). $\quad$ To a solution of $5 \mathrm{a}(0.46 \mathrm{~g}, 0.82 \mathrm{mmol})$ in dry methylene chloride $(60 \mathrm{~mL})$ stirring at $-78{ }^{\circ} \mathrm{C}$ was added $\mathrm{BBr}_{3}(8.2 \mathrm{mmol})$. The reaction was allowed to stir, under argon, at that temperature for 2 hours before gradually allowing it to warm to room temperature and stir overnight. It was then cooled to $0{ }^{\circ} \mathrm{C}$, quenched via careful addition of sat. aq. $\mathrm{NaHCO}_{3}$, and filtered to remove all solid material. The filtrate was then extracted with methylene chloride $(50 \mathrm{~mL} \times 3)$. The organics were then combined, dried over $\mathrm{MgSO}_{4}$, and evaporated in vacuo to afford $7 \mathbf{a}(0.38 \mathrm{~g}, 88 \%)$ as a brown solid: ${ }^{1} \mathrm{H} \mathrm{NMR}\left(\mathrm{CDCl}_{3}\right) \delta 3.80$ (s, 6H), 7.12 (t, $J=8.4 \mathrm{~Hz}, 3 \mathrm{H}), 7.30$ (t, $J=8.4 \mathrm{~Hz}, 6 \mathrm{H}), 7.47$ (d, $J=8.4 \mathrm{~Hz}, 6 \mathrm{H}), 7.99$ (s, 3H), 9.76 (s, $3 \mathrm{H}) .\left(\mathrm{DMSO}-d_{6}\right) \delta 3.71(\mathrm{~s}, 6 \mathrm{H}), 7.05(\mathrm{t}, J=7.5 \mathrm{~Hz}, 3 \mathrm{H}), 7.30(\mathrm{t}, J=7.5 \mathrm{~Hz}, 6 \mathrm{H}), 7.60(\mathrm{~d}, J=7.5 \mathrm{~Hz}$, $6 \mathrm{H}), 9.31(\mathrm{~s}, 3 \mathrm{H}), 10.20(\mathrm{~s}, 3 \mathrm{H}) .{ }^{13} \mathrm{C} \mathrm{NMR}\left(\mathrm{DMSO}-d_{6}\right) \delta 32.4,103.4,119.3,123.4,128.7,138.9$, 153.6, 171.6. HRMS (ESI) calcd for $\mathrm{C}_{30} \mathrm{H}_{27} \mathrm{~N}_{3} \mathrm{O}_{6}+\mathrm{Na}\left(\mathrm{M}^{+}\right)$548.1792, found 548.1818.

${ }^{15} \mathrm{~N}$-Phenyl-2-(2,4,6-trihydroxy-3,5-bis-phenylcarbamoylmethyl-phenyl)-acetamide (7a*). This compound was synthesized from $\mathbf{5 a} *(0.50 \mathrm{~g}, 0.77 \mathrm{mmol})$ and $\mathrm{BBr}_{3}(6.9 \mathrm{mmol})$ according to the same procedure used for 7a to afford $7 \mathbf{a} *(0.33 \mathrm{~g}, 71 \%):{ }^{1} \mathrm{H}$ NMR (DMSO- $\left.d_{6}\right) \delta 3.72(\mathrm{~s}, 6 \mathrm{H}), 7.05(\mathrm{t}, J=7.5$ $\mathrm{Hz}, 3 \mathrm{H}), 7.30(\mathrm{t}, J=7.8 \mathrm{~Hz}, 6 \mathrm{H}), 7.60(\mathrm{~d}, J=8.4 \mathrm{~Hz}, 6 \mathrm{H}), 9.32(\mathrm{~s}, 3 \mathrm{H}), 10.18(\mathrm{~d}, 90.6 \mathrm{~Hz}, 3 \mathrm{H}) .{ }^{13} \mathrm{C}$ NMR (DMSO- $\left.d_{6}\right) \delta 32.8,103.9,119.8,123.9,129.1,139.4,154.1,171.9$. HRMS (EI) calcd for $\mathrm{C}_{30} \mathrm{H}_{27}{ }^{15} \mathrm{~N}_{3} \mathrm{O}_{6}\left(\mathrm{M}^{+}\right)$528.1900, found 528.1987.

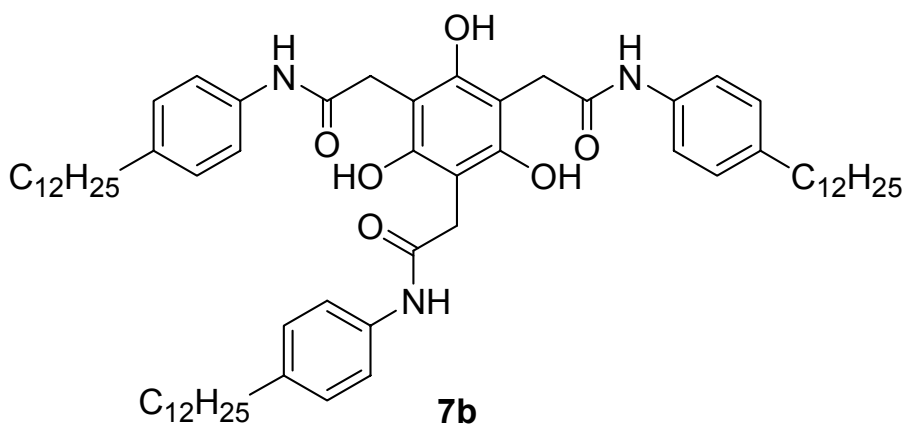

2-\{3,5-Bis-[(4-dodecyl-phenylcarbamoyl)-methyl]-2,4,6-trihydroxy-phenyl\}- $N$-(4-dodecylphenyl)-acetamide (7b). This compound was synthesized from $\mathbf{5 b}(1.00 \mathrm{~g}, 0.93 \mathbf{m m o l})$ and $\mathrm{BBr}_{3}(9.3$ $\mathrm{mmol})$ according to the same procedure used for $7 \mathbf{a}$ to afford $7 \mathbf{b}(0.797 \mathrm{~g}, 83 \%)$ : ${ }^{1} \mathrm{H} \mathrm{NMR}\left(\mathrm{CDCl}_{3}\right) \delta$ 
$0.88(\mathrm{t}, J=7.2 \mathrm{~Hz}, 9 \mathrm{H}), 1.25(\mathrm{~m}, 54 \mathrm{H}), 1.55(\mathrm{~m}, 6 \mathrm{H}), 2.54(\mathrm{t}, J=7.2 \mathrm{~Hz}, 6 \mathrm{H}), 3.78(\mathrm{~s}, 6 \mathrm{H}), 7.09(\mathrm{~d}, J=$ $7.8 \mathrm{~Hz}, 6 \mathrm{H}), 7.36(\mathrm{~d}, J=7.5 \mathrm{~Hz}, 6 \mathrm{H}), 7.81(\mathrm{~s}, 3 \mathrm{H}), 9.77(\mathrm{~s}, 3 \mathrm{H})$. (DMSO-d $) \delta 0.84(\mathrm{t}, J=6.9 \mathrm{~Hz}, 9 \mathrm{H})$, $1.22(\mathrm{~m}, 54 \mathrm{H}), 1.51(\mathrm{~m}, 6 \mathrm{H}), 2.48(\mathrm{~m}, 6 \mathrm{H}), 3.70(\mathrm{~s}, 6 \mathrm{H}), 7.09(\mathrm{~d}, J=8.4 \mathrm{~Hz}, 6 \mathrm{H}), 7.49(\mathrm{~d}, J=8.1 \mathrm{~Hz}$, $6 \mathrm{H}), 9.55(\mathrm{~s}, 3 \mathrm{H}), 10.30(\mathrm{~s}, 3 \mathrm{H}) .{ }^{13} \mathrm{C} \mathrm{NMR}\left(\mathrm{DMSO}-d_{6}\right) \delta 14.4,16.4,22.6,29.2,29.5,31.4,31.8,35.0$, 39.2 , 103.4, 120.0, 128.8, 137.9, 143.5, 157.5, 170.1. HRMS (ESI) calcd for $\mathrm{C}_{66} \mathrm{H}_{99} \mathrm{~N}_{3} \mathrm{O}_{6}+\mathrm{Na}\left(\mathrm{M}^{+}\right)$ 1052.7426, found 1052.7405.

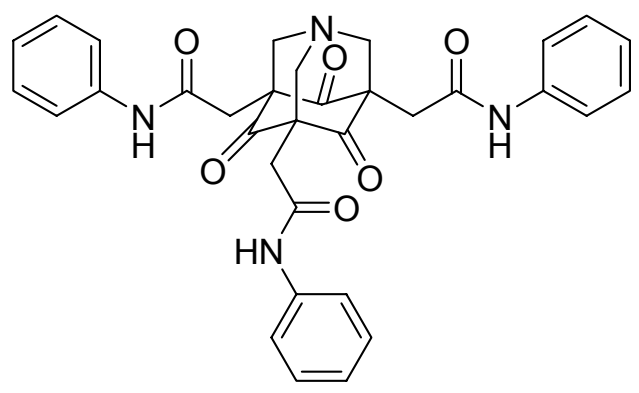

$2 a$

$N$-Phenyl-2-(4,6,10-trioxo-5,7-bis-phenylcarbamoylmethyl-1-aza-tricyclo[3.3.1.1 $\left.{ }^{3,7}\right]$ dec-3-yl)acetamide (2a). A solution of $\mathbf{6 a}(0.37 \mathrm{~g}, 0.71 \mathrm{mmol})$, HMTA $(0.010 \mathrm{~g}, 0.71 \mathrm{mmol})$, and isopropanol $(20 \mathrm{~mL})$ was heated to reflux for 12 hours. After cooling the reaction mixture to room temperature the mixture was suction filtered to separate $2 \mathbf{a}(0.176 \mathrm{~g}, 43 \%)$ as a purple flaky solid: ${ }^{1} \mathrm{H}$ NMR (DMSO- $\left.d_{6}\right)$ $\delta 2.77(\mathrm{~s}, 6 \mathrm{H}), 3.92(\mathrm{~s}, 6 \mathrm{H}), 7.00(\mathrm{t}, J=7.5 \mathrm{~Hz}, 3 \mathrm{H}), 7.26(\mathrm{t}, J=7.5 \mathrm{~Hz}, 6 \mathrm{H}), 7.54(\mathrm{~d}, J=8.4 \mathrm{~Hz}, 6 \mathrm{H})$, $10.02(\mathrm{~s}, 3 \mathrm{H}) .{ }^{13} \mathrm{C} \mathrm{NMR}\left(\mathrm{DMSO}-d_{6}\right) \delta 34.3,70.7,70.9,119.3,123.3,129.1,139.8,168.0,198.8$. IR (Nujol) v 3361 (amide -NH), 1742 (ketone $\mathrm{C}=\mathrm{O}$ ), 1698 (ketone $\mathrm{C}=\mathrm{O}), 1660$ (amide $\mathrm{I}, \mathrm{C}=\mathrm{O}$ ) $\mathrm{cm}^{-1}$. $\mathrm{UV} / \mathrm{Vis}\left(\mathrm{CH}_{3} \mathrm{CN}\right) \lambda_{\max }(\varepsilon)=240 \mathrm{~nm}(24300)$. HRMS (ESI) calcd for $\mathrm{C}_{33} \mathrm{H}_{30} \mathrm{~N}_{4} \mathrm{O}_{6}+\mathrm{Na}\left(\mathrm{M}^{+}\right) 601.2058$, found 601.2053 .

\section{${ }^{15} \mathrm{~N}$-Phenyl-2-(4,6,10-trioxo-5,7-bis-phenylcarbamoylmethyl-1-aza-tricyclo[3.3.1.13,7]dec-3-yl)-} acetamide (2a*). This compound was synthesized from 6a* $(0.30 \mathrm{~g}, 0.57 \mathrm{mmol})$, HMTA $(0.080 \mathrm{~g}$, $0.57 \mathrm{mmol})$, and isopropanol $(20 \mathrm{~mL})$ according to the same procedure reported for $\mathbf{2 a}$ to afford $\mathbf{2 a}$ * $(0.18 \mathrm{~g}, 53 \%)$ as a blue-purple solid: ${ }^{1} \mathrm{H}$ NMR $\left(\mathrm{DMSO}-d_{6}\right) \delta 2.78(\mathrm{~s}, 6 \mathrm{H}), 3.93(\mathrm{~s}, 6 \mathrm{H}), 7.00(\mathrm{t}, J=7.5$ $\mathrm{Hz}, 3 \mathrm{H}), 7.26(\mathrm{t}, J=7.5 \mathrm{~Hz}, 6 \mathrm{H}), 7.54(\mathrm{~d}, J=7.5 \mathrm{~Hz}, 6 \mathrm{H}), 10.00(\mathrm{~d}, J=90.3 \mathrm{~Hz}, 3 \mathrm{H})$. (pyridine- $\left.d_{5}\right) \delta$ $3.29(\mathrm{~s}, 6 \mathrm{H}), 4.28(\mathrm{~s}, 6 \mathrm{H}), 7.08(\mathrm{t}, J=7.8 \mathrm{~Hz}, 3 \mathrm{H}), 7.32(\mathrm{t}, J=7.8 \mathrm{~Hz}, 6 \mathrm{H}), 7.96(\mathrm{~d}, J=7.8 \mathrm{~Hz}, 6 \mathrm{H})$, $10.96(\mathrm{~d}, J=89.1 \mathrm{~Hz}, 3 \mathrm{H}) .{ }^{13} \mathrm{C}$ NMR (pyridine- $\left.d_{5}\right) \delta 35.3,71.6,71.8,120.6,129.6,140.8,141.0$, 169.2, 199.7. HRMS (ESI) calcd for $\mathrm{C}_{33} \mathrm{H}_{30} \mathrm{~N}^{15} \mathrm{~N}_{3} \mathrm{O}_{6}+\mathrm{Na}\left(\mathrm{M}^{+}\right) 604.1968$, found 604.1981.

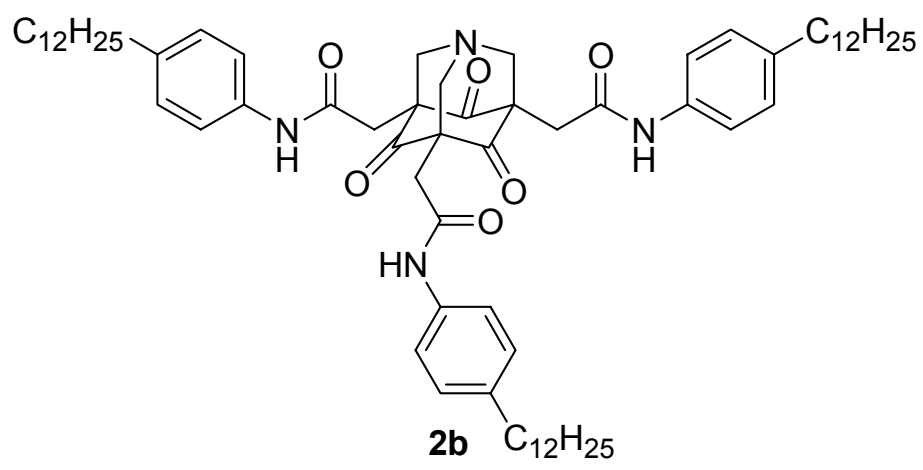

2-\{5,7-Bis-[(4-dodecyl-phenylcarbamoyl)-methyl]-4,6,10-trioxo-1-aza-tricyclo[3.3.1.1 $\left.{ }^{3,7}\right]$ dec-3-yl\}$\boldsymbol{N}$-(4-dodecyl-phenyl)-acetamide (2b). A solution of $\mathbf{6 b}(0.50 \mathrm{~g}, 0.49 \mathrm{mmol})$, HMTA (0.070 g, 0.49 
$\mathrm{mmol})$ and isopropanol $(50 \mathrm{~mL})$ was refluxed for 12 hours under a blanket of argon. After cooling the reaction mixture to room temperature, the solvent was removed in vacuo and the residue partitioned in ethyl acetate $(100 \mathrm{~mL})$. The solid was collected by suction filtration and purified via recrystallization from ethyl acetate/dioxane to afford $\mathbf{2 b}(0.18 \mathrm{~g}, 35 \%)$ as a colorless solid: ${ }^{1} \mathrm{H}$ NMR (DMSO- $\left.d_{6}\right) \delta 0.85$ $(\mathrm{t}, J=6.9 \mathrm{~Hz}, 9 \mathrm{H}), 1.22(\mathrm{~m}, 54 \mathrm{H}), 1.50(\mathrm{~m}, 6 \mathrm{H}), 2.49(\mathrm{~m}, 6 \mathrm{H}), 2.74(\mathrm{~s}, 6 \mathrm{H}), 3.90(\mathrm{~s}, 6 \mathrm{H}), 7.05(\mathrm{~d}, J=$ $8.4 \mathrm{~Hz}, 6 \mathrm{H}), 7.42(\mathrm{~d}, J=8.4 \mathrm{~Hz}, 6 \mathrm{H}), 9.90(\mathrm{~s}, 3 \mathrm{H})$. (pyridine- $\left.d_{5}\right) \delta 0.88(\mathrm{t}, J=7.2 \mathrm{~Hz}, 9 \mathrm{H}), 1.26(\mathrm{~m}$, $54 \mathrm{H}), 1.60(\mathrm{~m}, 6 \mathrm{H}), 2.57(\mathrm{t}, J=7.2 \mathrm{~Hz}, 6 \mathrm{H}), 3.31(\mathrm{~s}, 6 \mathrm{H}), 4.30(\mathrm{~s}, 6 \mathrm{H}), 7.21(\mathrm{~m}, 6 \mathrm{H}), 7.93(\mathrm{~d}, J=8.4$ $\mathrm{Hz}, 6 \mathrm{H}), 10.93(\mathrm{~s}, 3 \mathrm{H}) .\left(\mathrm{CDCl}_{3}\right.$ at $\left.50{ }^{\circ} \mathrm{C}\right) \delta 0.90(\mathrm{t}, J=6.3 \mathrm{~Hz}, 9 \mathrm{H}), 1.28(\mathrm{~m}, 54 \mathrm{H}), 1.60(\mathrm{~m}, 6 \mathrm{H}), 2.58$ $(\mathrm{t}, J=7.2 \mathrm{~Hz}, 6 \mathrm{H}), 2.91(\mathrm{~s}, 6 \mathrm{H}), 3.84(\mathrm{~s}, 6 \mathrm{H}), 7.10(\mathrm{~d}, J=8.1 \mathrm{~Hz}, 6 \mathrm{H}), 7.36(\mathrm{~d}, J=7.8 \mathrm{~Hz}, 6 \mathrm{H}), 7.62(\mathrm{~s}$, $3 \mathrm{H}) .{ }^{13} \mathrm{C}$ NMR (pyridine- $\left.d_{5}\right) \delta 14.5,23.1,30.1,32.2,35.1,35.9,71.4,71.7,120.8,129.1,138.1,138.7$, 168.3, 199.1. IR $\left(\mathrm{CHCl}_{3}, 3.4 \mathrm{mM}\right) v 3365$ (amide -NH), 1738 (ketone $\mathrm{C}=\mathrm{O}$ ), 1700 (ketone $\mathrm{C}=\mathrm{O}$ ), 1658 (amide I, C=O), 1599 (amide II, C=O) $\mathrm{cm}^{-1}$. HRMS (ESI) calcd for $\mathrm{C}_{69} \mathrm{H}_{102} \mathrm{~N}_{4} \mathrm{O}_{6}+\mathrm{Na}\left(\mathrm{M}^{+}\right.$) 1105.7692, found 1105.7733.

\section{NMR EXPERIMENTS AND DATA}

Routine ${ }^{\mathbf{1}} \mathbf{H}$ NMR Spectra. ${ }^{1} \mathrm{H}$ NMR spectra (300 MHz) for $\mathbf{2}-\mathbf{5}$ and $\mathbf{7}$ are attached (pages 8-18).

-NH Temperature Coefficient Determination for $\mathbf{2 b}$ in $\mathbf{C}_{\mathbf{2}} \mathbf{D}_{\mathbf{2}} \mathbf{C l}_{\mathbf{4}}$. A sample of $\mathbf{2 b}$ was prepared in $\mathrm{C}_{2} \mathrm{D}_{2} \mathrm{Cl}_{4}$ at $13 \mathrm{mM}$. The temperature dependence of the $-\mathrm{NH}$ chemical shift was followed in a series of 7 spectra from $298 \mathrm{~K}$ to $398 \mathrm{~K}$ as shown graphically below. Since the variation of chemical shifts with the temperature displayed good linearity $\left(R^{2}=0.99\right)$, the temperature coefficient of the chemical shifts was measured as $[\delta(398 \mathrm{~K})-\delta(298 \mathrm{~K})] / 100 * 1000$, in $\mathrm{ppb} / \mathrm{K}$. The temperature recorded was the one indicated by the thermocouple in the probe. The chemical shifts were determined based on residual protonated solvent where the analysis assumes that the reference signal position is temperature independent. ${ }^{[2]}$

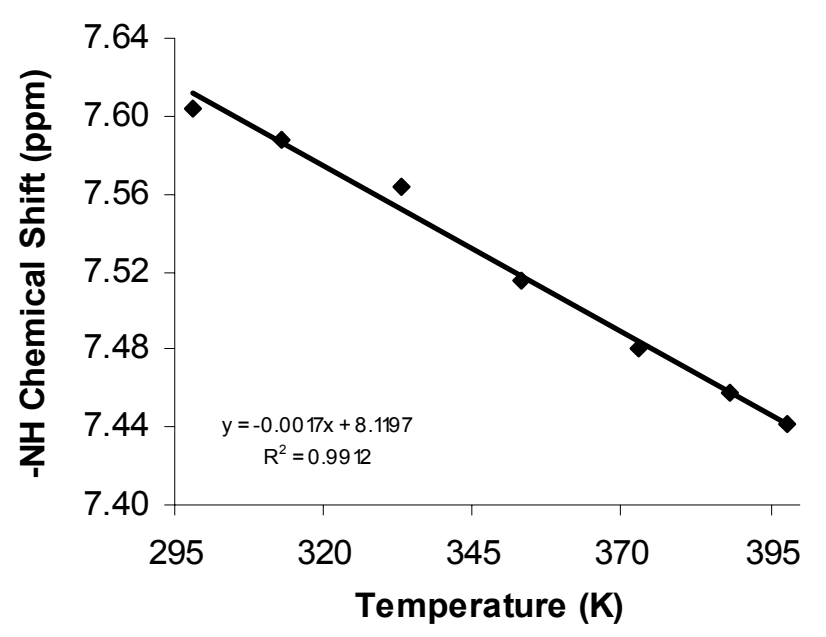

Solid-State ${ }^{15} \mathrm{~N}$ and ${ }^{13} \mathrm{C}$ CPMAS (Charge Polarized Magic Angle Spinning) NMR Spectra of 2a*. ${ }^{13} \mathrm{C}$ and ${ }^{15} \mathrm{~N}$ CPMAS spectra were recorded with the dry monomer $2 \mathbf{a}^{*}$ on a Bruker DRX500 spectrometer using a Doty XC4 probe. Powdered samples were spun at $8 \mathrm{kHz}$ and high power $(>100$ $\mathrm{kHz}$ ) proton decoupling was applied during acquisition. The ${ }^{15} \mathrm{~N}$ spectrum is referenced to nitromethane by setting the observed nitrogen signal of $\left({ }^{15} \mathrm{NH}_{4}\right)_{2} \mathrm{SO}_{4}$ to $-355.8 \mathrm{ppm}$. The ${ }^{13} \mathrm{C}$ spectrum is referenced to TMS by setting the methylene $\left(-\mathrm{CH}_{2}\right)$ carbon signal of adamantane to $38.5 \mathrm{ppm}$. We are grateful to Prof. Joanna Long for assistance with the spectra. 


\section{IR MEASUREMENTS}

IR measurements were performed at $25{ }^{\circ} \mathrm{C}$ on either a Perkin-Elmer Spectrum One spectrometer or a Bruker Vector 22 spectrometer using a solution cell equipped with $\mathrm{NaCl}$ plates. The spectra shown in Figure 4 are base line corrected.

\section{XRD DATA}

General. The compounds 2 were loaded into $1 \mathrm{~mm}$ glass capillary tubes purchased from Charles Supper Co. (Natick, MA). Samples were rotated around the long axis of the capillary to average out any effects of preferential orientation. The X-ray diffraction measurements were performed on an INEL CPS 120 using Ni filtered $\mathrm{Cu} \mathrm{K \alpha}$ X-rays. The instrument was calibrated with a mixture of yttrium oxide and silver behenate. We are grateful to Dana Horoszewski and Prof. Colin Nuckolls for assistance with the measurements.
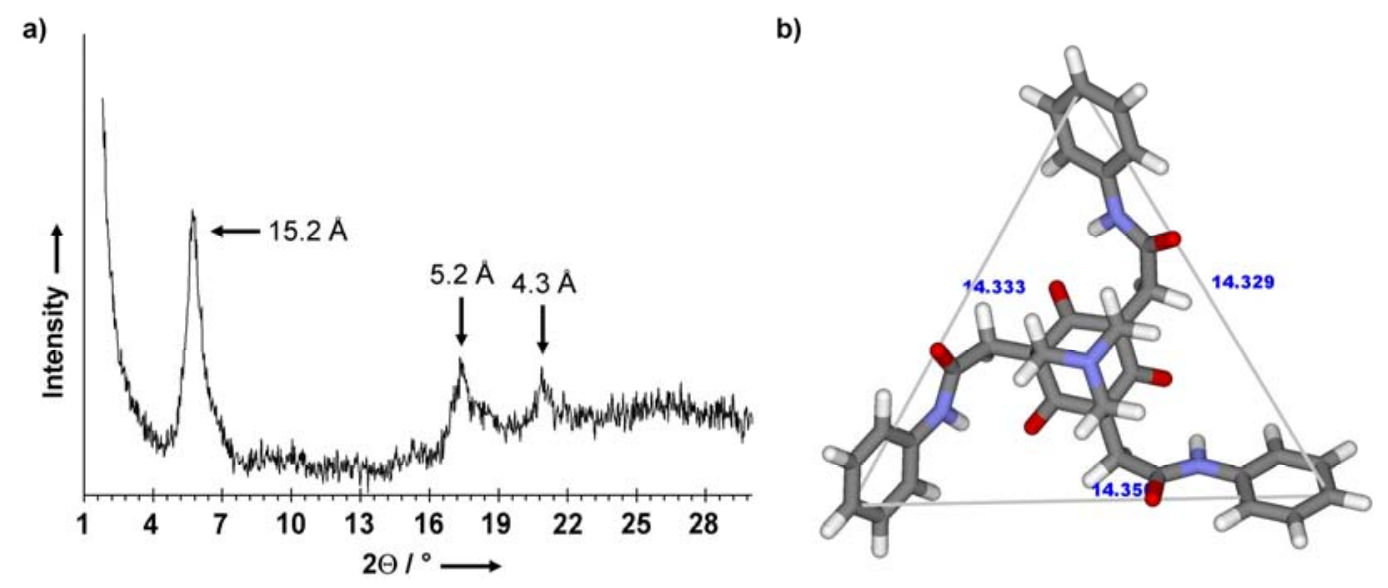

XRD Data of 2a. a) XRD spectrum of 2a taken at $21^{\circ} \mathrm{C}$. The peak corresponding to a $d$-spacing of $15.2 \AA$ is on the order the size of the monomer (in $\AA$ ), shown as its energy-minimized model shown in (b). For the given edge dimensions of the monomer in a $C_{3}$-symmetric conformation, the corresponding circumscribed circle diameter would be $16.5 \AA$. Also observed are two higher-angle peaks at $d=5.2$ and $d=4.3 \AA$. The $5.2 \AA$ spacing may arise from either the intercore distance within columns of molecules (calculated as $\sim 5.5 \AA$ ) or the higher-order $(003)$ reflection $(5.1 \AA)$. The $4.3 \AA$ spacing most likely represents packing of the phenyl side chains.

\section{GEL PROPERTIES}

Representative Gel Formation. 1-Aza-adamantanetrione $2 \mathbf{b}\left(18.7 \mathrm{mg}, 0.5 \%\right.$ by weight) and $\mathrm{CHCl}_{3}$ $(2.5 \mathrm{~mL})$ were combined in a sealed vial. The vial was then heated with a heat gun until a homogenous solution was formed. The vial was then allowed to gradually cool to room temperature on the bench top, during which time the gel rapidly formed (ca. 5 minutes).

$\boldsymbol{T}_{\text {gel }}$ Determination. ${ }^{[3]}$ Organogels of $\mathbf{2 b}$ in $\mathrm{CHCl}_{3}$ with a volume of $1.0 \mathrm{~mL}$ were prepared in vials with a diameter of $10 \mathrm{~mm}$. After the gel had aged for at least 12 hours at $25{ }^{\circ} \mathrm{C}$, a steel ball with a diameter of $2 \mathrm{~mm}$ was placed on top of the gel, the vial resealed, and placed in an oil bath. The temperature was slowly increased (ca. $0.5{ }^{\circ} \mathrm{C} / \mathrm{min}$ ), and monitored using a thermometer submerged in a vial containing neat $\mathrm{CHCl}_{3}$ also in the oil bath, while observing the position of the steel ball. The temperature at which the ball touched the bottom of the vial was taken as the $T_{\text {gel }}$ temperature. This 
experiment was carried out three times, and the $T_{\text {gel }}$ temperatures obtained were reproducible to within $\pm 2{ }^{\circ} \mathrm{C}$.

Xerogel Preparation. A vial containing the organogel of $\mathbf{2 b}$ in $\mathrm{CHCl}_{3}$ was frozen in liquid nitrogen and transferred to a freeze dry system (Labconco FreeZone 4.5 liter) overnight. In a similar preparation a standard freeze-pump-thaw procedure was used.

Xerogel Analysis by SEM. Some of the xerogel was flaked onto a 01801 Formvar/Carbon 200 mesh copper grid (Ted Pella, Inc.). The sample was then sputter-coated with a thin layer of amorphous carbon and imaged on a JEOL JSM-6335f Field Emission Scanning Electron Microscope. We are grateful to Dr. Kerry Siebein for assistance with the analysis.

\section{Vi. Computational Details}

Monte Carlo Conformational Searching and Geometry Minimizations. All Monte Carlo calculations were performed on a Dell PC $(2.4 \mathrm{GHz})$ running the Fedora Core. Monte Carlo conformational searching was done using MacroModel v. 9.0 (Schrodinger, LLC) ${ }^{[4]}$ and the MCMM method. For the model shown in Figure 3a, relevant parameters include: steps $=500$, iterations $=5000$, solvent $(\mathrm{GB} / \mathrm{SA})=\mathrm{CHCl}_{3}$, force field $=$ Amber*. The lowest energy "all-arms-up" conformer and the lowest energy "all-arms-down" conformer (in addition to other low-energy conformers) identified were further refined first at the HF/3-21G* level and then the HF/6-31G* level using Gaussian 03 (revision B.04) ${ }^{[5]}$ as implemented through the UF Dell HPC Cluster (http://hpc.ufl.edu/DellCluster/index.html). The relative energies are reported based on these calculations.

VII. COPIES OF ${ }^{1} \mathrm{H}$ NMR SPECTRA (SEE THE FOLLOWING PAGES) 
Supporting Information

Lampkins, et al.

$S I S^{\circ} \mathcal{E}$

It $9^{\circ} \mathcal{E}$

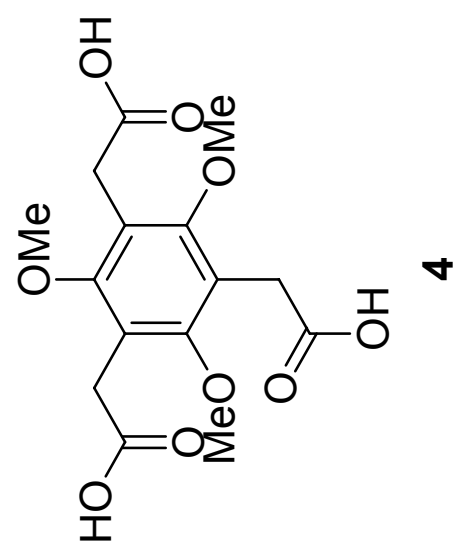



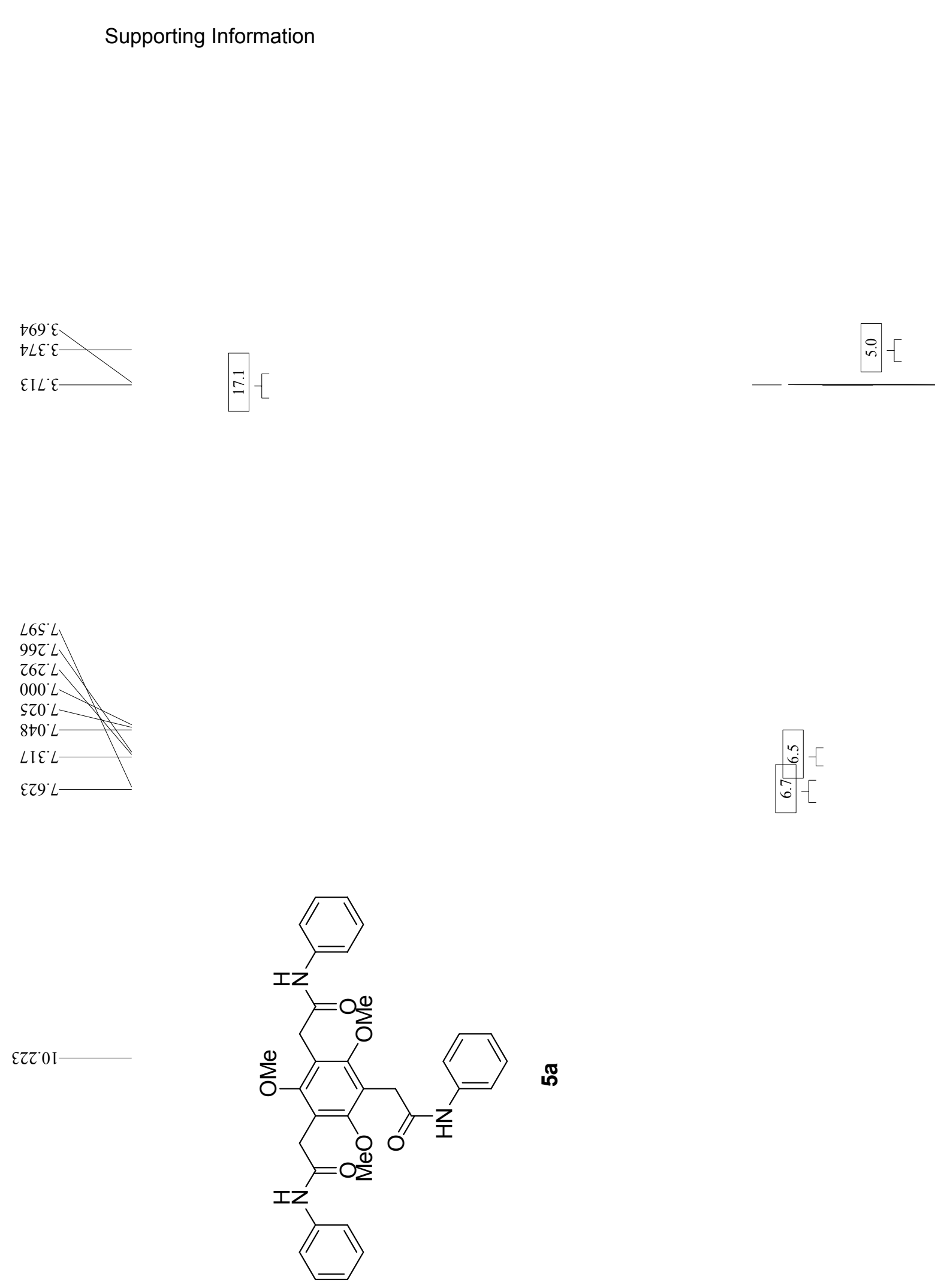
$\subseteq 69^{\circ} \varepsilon$

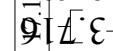

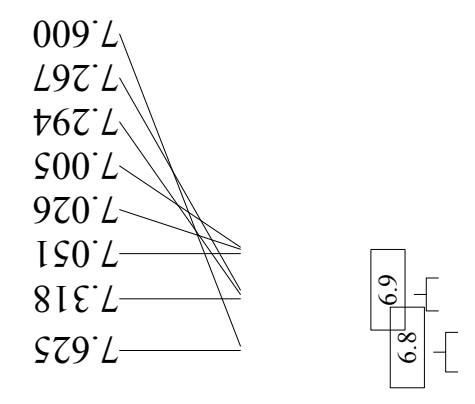

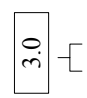

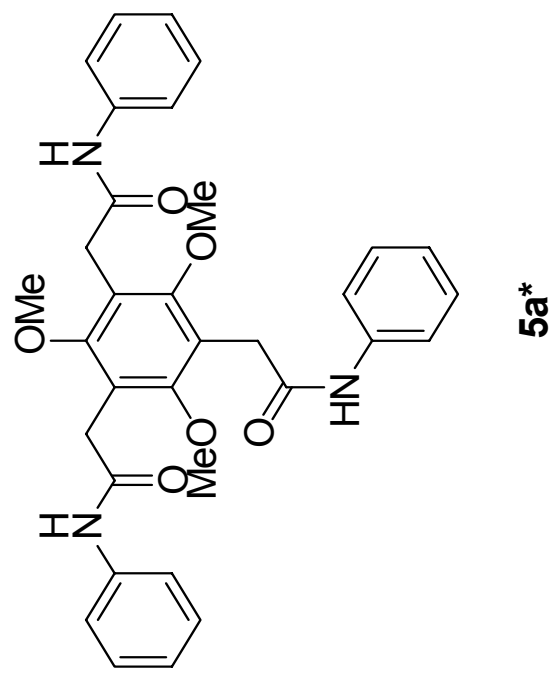

గ

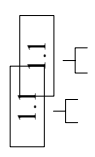




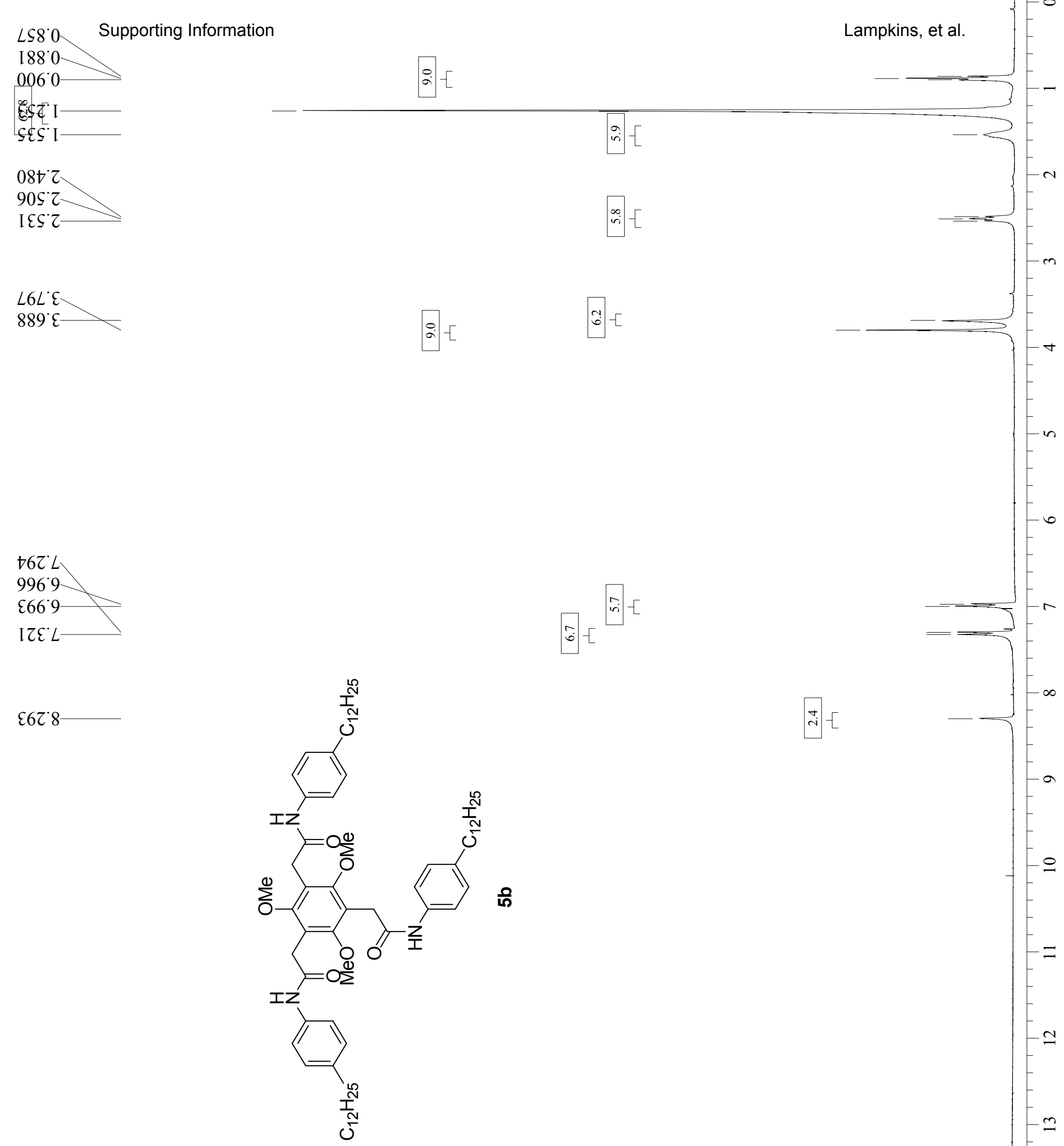

$762^{\circ} \mathrm{L}$

$996^{\circ} 9$

$\mathcal{E} 66^{\circ} 9$

5 

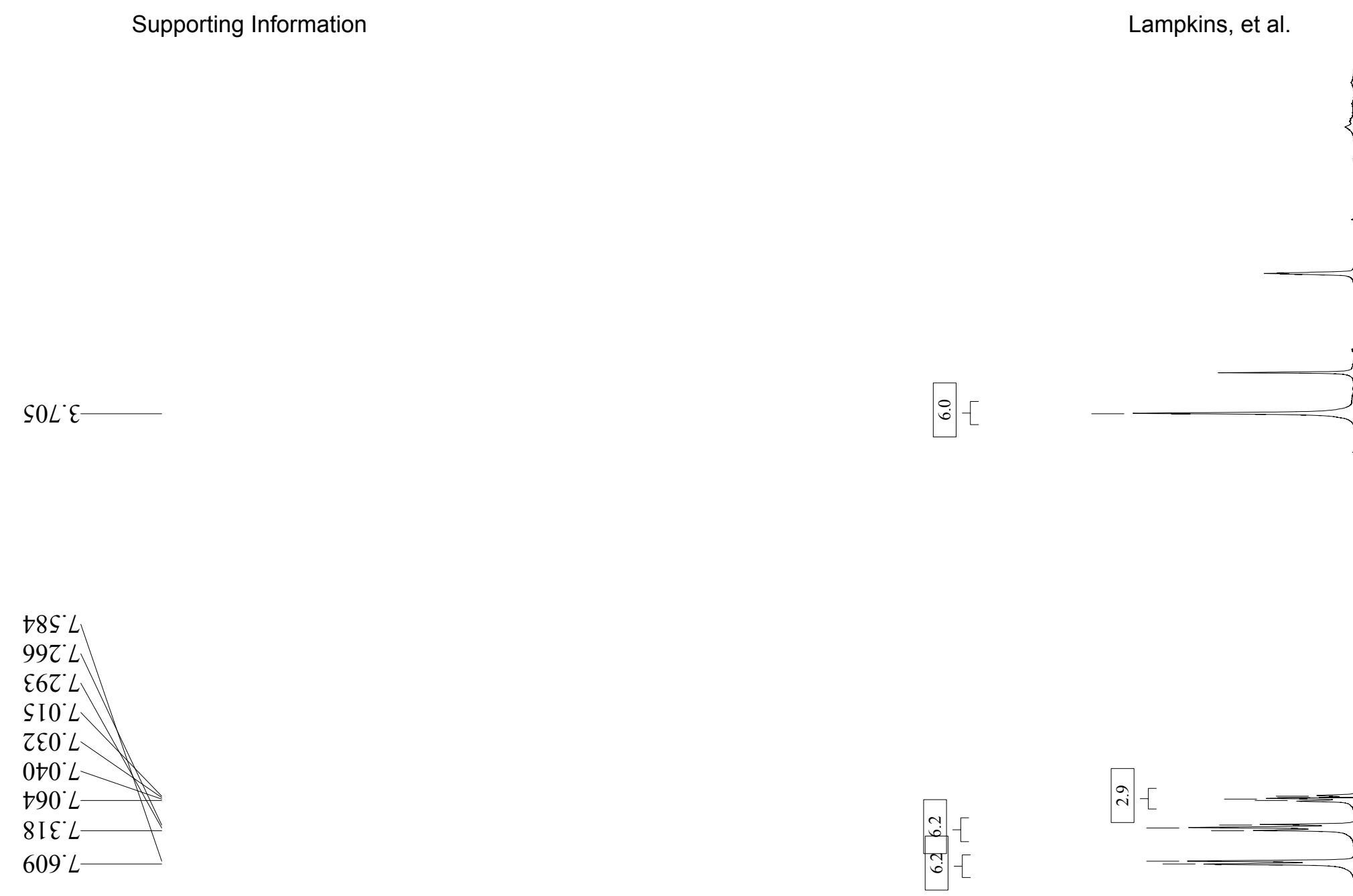

DIE'6
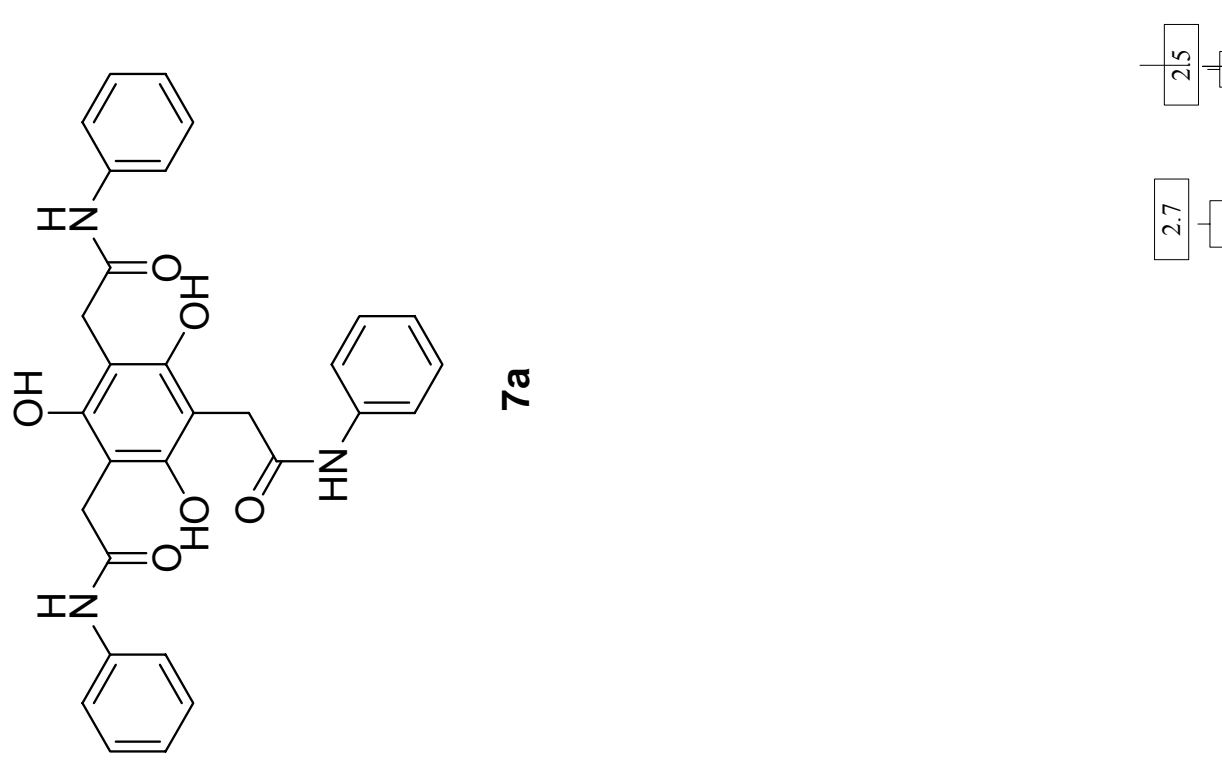<smiles>C1C2CC3CC1C3C2</smiles> 

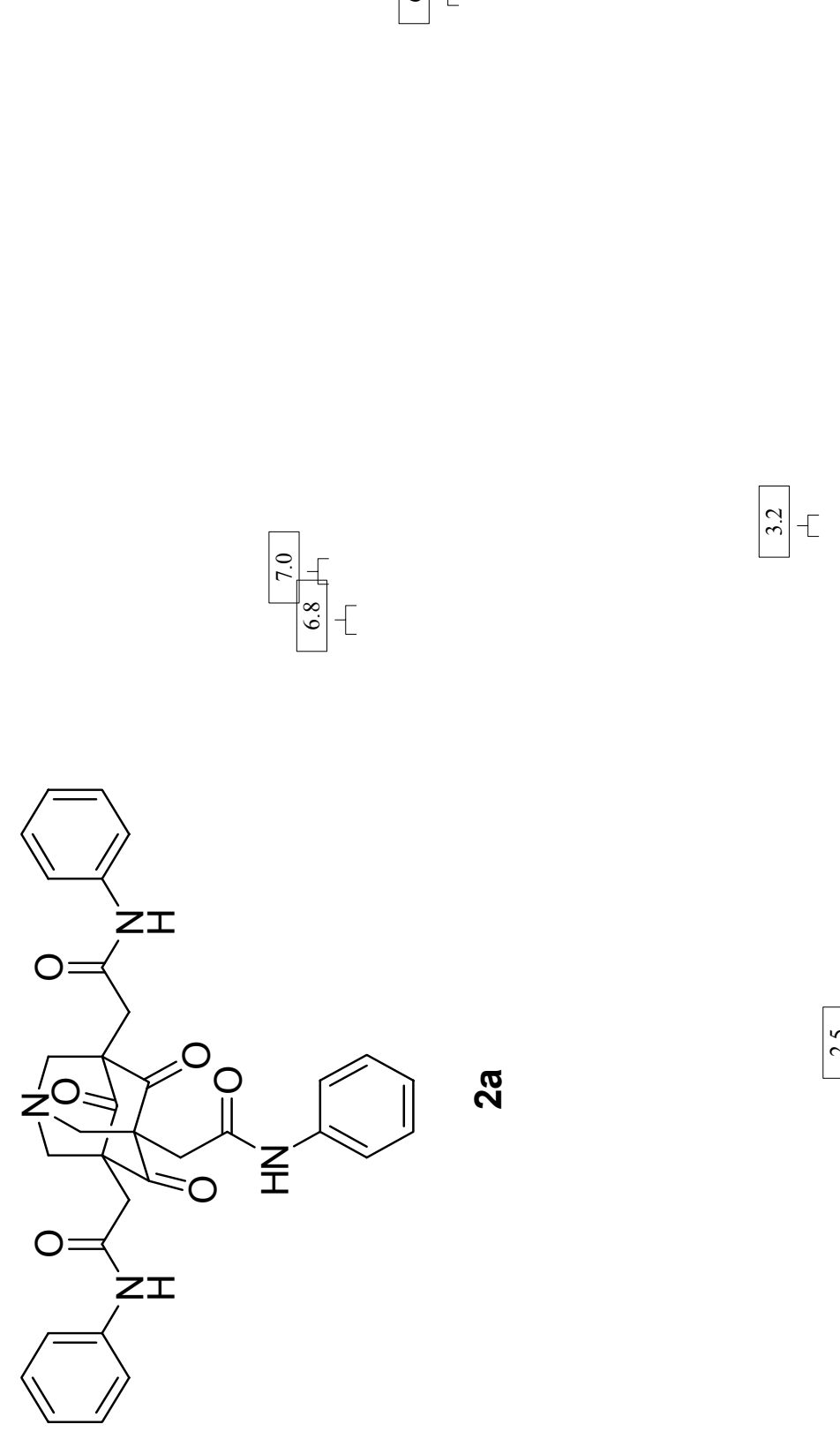
$9 L L \cdot Z$

$926^{\circ} \mathcal{\varepsilon}$

ZEZ:L

$6 \subseteq Z^{\circ} L$

$78 Z^{\circ} L$

$\angle L 6^{\circ} 9$

$866^{\circ} 9$

$\varepsilon Z 0^{\circ} \mathrm{L}$

$\nabla Z S^{\circ} L$

$6+S^{\circ} L$

$678^{\circ} 6$

$0 \varsigma \mathrm{I}^{\circ} 0 \mathrm{I}-$
0

엄- -

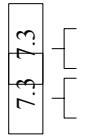

Lampkins, et al.

\section{$\bar{m} \cdot-[$}
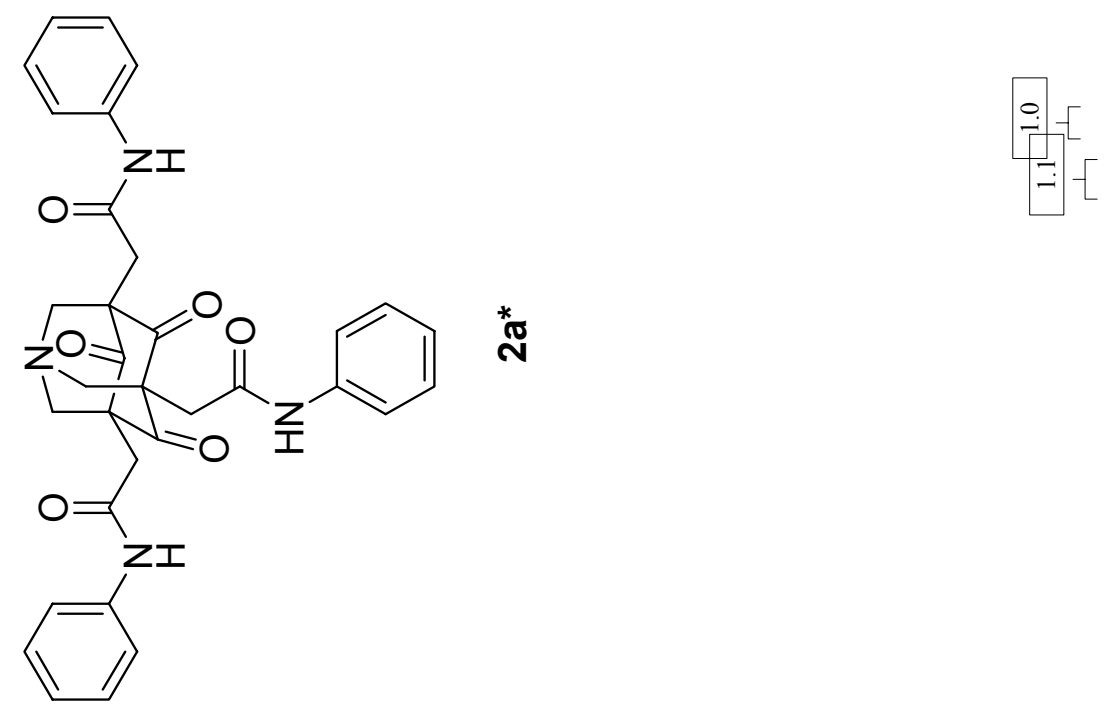


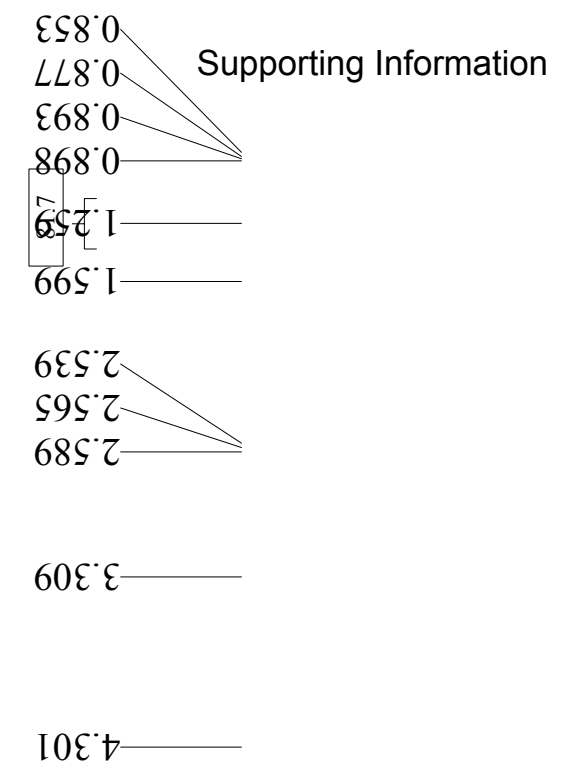

$\stackrel{0}{\stackrel{+}{-}-[}$

7

$\underset{0}{0}-[$

$\infty \begin{aligned} & \infty \\ & i \\ & i\end{aligned}-[$

$\varepsilon 0 Z^{*} L$

I $E Z^{\circ} L$

$076^{\circ} \mathrm{L}$

$876^{\circ} \mathrm{L}$

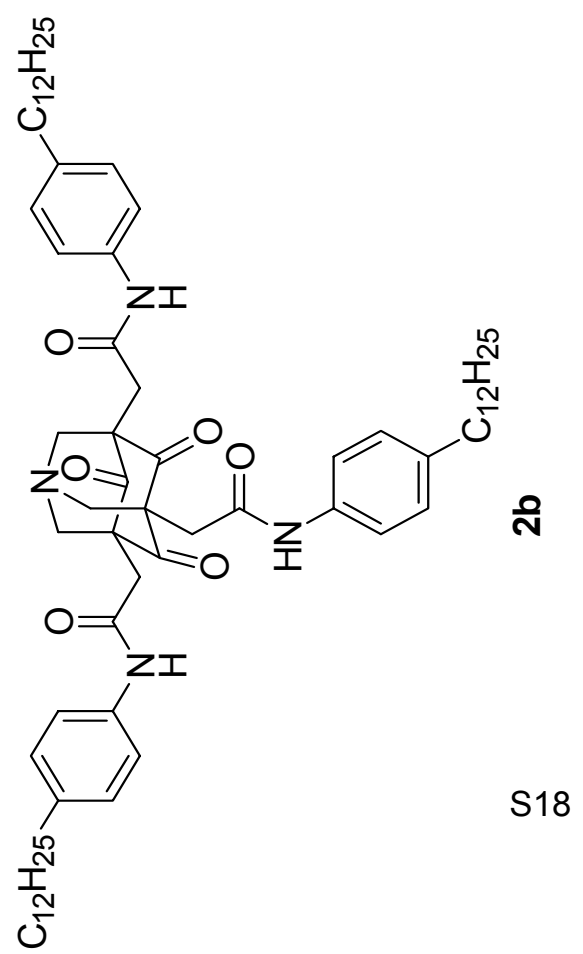




\section{REFERENCES}

[1] H. F. Li, E. A. Homan, A. J. Lampkins, I. Ghiviriga, R. K. Castellano, Org. Lett. 2005, 7, $443-446$.

[2] S. H. Gellman, G. P. Dado, G. B. Liang, B. R. Adams, J. Am. Chem. Soc. 1991, 113, 1164-1173.

[3] J. Brinksma, B. L. Feringa, R. M. Kellogg, R. Vreeker, J. van Esch, Langmuir 2000, 16, 9249-9255.

[4] Mohamadi, F.; Richards, N. G.; Guida, W. C.; Liskamp, R.; Lipton, M.; Caufield, C.; Chang, G.; Hendrickson, T.; Still, W. C. J. Comput. Chem. 1990, 11, 440-467.

[5] M. J. Frisch, G. W. Trucks, H. B. Schlegel, G. E. Scuseria, M. A. Robb, J. R. Cheeseman, J. A. Montgomery, Jr., T. Vreven, K. N. Kudin, J. C. Burant, J. M. Millam, S. S. Iyengar, J. Tomasi, V. Barone, B. Mennucci, M. Cossi, G. Scalmani, N. Rega, G. A. Petersson, H. Nakatsuji, M. Hada, M. Ehara, K. Toyota, R. Fukuda, J. Hasegawa, M. Ishida, T. Nakajima, Y. Honda, O. Kitao, H. Nakai, M. Klene, X. Li, J. E. Knox, H. P. Hratchian, J. B. Cross, V. Bakken, C. Adamo, J. Jaramillo, R. Gomperts, R. E. Stratmann, O. Yazyev, A. J. Austin, R. Cammi, C. Pomelli, J. W. Ochterski, P. Y. Ayala, K. Morokuma, G. A. Voth, P. Salvador, J. J. Dannenberg, V. G. Zakrzewski, S. Dapprich, A. D. Daniels, M. C. Strain, O. Farkas, D. K. Malick, A. D. Rabuck, K. Raghavachari, J. B. Foresman, J. V. Ortiz, Q. Cui, A. G. Baboul, S. Clifford, J. Cioslowski, B. B. Stefanov, G. Liu, A. Liashenko, P. Piskorz, I. Komaromi, R. L. Martin, D. J. Fox, T. Keith, M. A. Al-Laham, C. Y. Peng, A. Nanayakkara, M. Challacombe, P. M. W. Gill, B. Johnson, W. Chen, M. W. Wong, C. Gonzalez, and J. A. Pople, Gaussian, Inc., Wallingford CT, 2004. 